\title{
Commentary
}

\section{Planning in/for/with the Public}

\author{
Ulf Strohmayer
}

School of Geography \& Archaeology, The National University of Ireland, H91 TK33 Galway, Ireland;

E-Mail: ulf.strohmayer@nuigalway.ie

Submitted: 23 February 2016 | Accepted: 3 March 2016 | Published: 18 March 2016

\begin{abstract}
This commentary traces key issues attaching to the use of the word 'public' within planning practices and theories. It argues for an alternative, non-binary engagement with public practices that may profit from being cast in a Foucauldian language and epistemology.
\end{abstract}

\section{Keywords}

alternative practices; dispositive; Foucauldian language; public sphere

\section{Issue}

This commentary is part of the issue "Urban Forms and Future Cities", edited by Luca D'Acci (Erasmus University Rotterdam, The Netherlands), Tigran Haas (KTH Royal Institute of Technology, Sweden) and Ronita Bardhan (Indian Institute of Technology Bombay, India).

(C) 2016 by the author; licensee Cogitatio (Lisbon, Portugal). This article is licensed under a Creative Commons Attribution 4.0 International License (CC BY).

Urban planning in general, and discursively motivated practices attaching to urban form in particular, are beholden in many ways to notions of a 'public'. In fact, it would not be an exaggeration to say that urban planners continue to grapple with the idea and reality of the 'public' in many relevant contexts. It is also one of those terms that are customarily invoked when urban planning makes headlines in different media: from concerns over 'public' access to public consultation processes, from normative practices embedded in a 'public sphere' to public relations, from 'public sector' involvement through 'public' policy to the everyday concerns of 'public' housing and 'public' transport-the notion of something 'public' marks a dimension we as planning practitioners or theoreticians (or both) ignore at our individual and collective peril. This brief intervention aims to illuminate the outer contours of this 'grappling' in an attempt to open up future productive conversations in the pages of Urban Planning. There are at least three aspects of 'the public' that concern us here.

The first of these and arguably the aspect commonly associated with the word 'public' in many presentday contexts emerges within the history of urban planning in Europe. Indeed, it is at the turn of the $17^{\text {th }}$ century that we can locate the origins of modern urban planning - as distinct from largely undirected urbanisation processes more generally or earlier notions of the 'ideal city' - in the articulations of concerns for 'a public' in practices associated with Henri IV and his grand commissioner of highways and public works, Maximilien de Béthune, Duke de Sully. In these practices, urban planning began to influence the design of public spaces as key in the improvement of the quality of urban life. A result of such meddling in urban affairs sees a more clearly articulated distinction between 'public' and 'private' spaces emerge, according to both different instruments in the developing practices of urban planning. The urban spaces that remain from such concerns with and for a 'public' - squares, streets, institutional buildings, parks-often serve as material mementos of these 'public' concerns, as do the laws, decrees and ordonnances that regulated the conditions of their possibility and development (see Ballon, 1991; DeJean, 2014; Strohmayer, 2010). However, decades of neo-liberal privatisations attaching to the public realm (broadly construed) have put an end to this historical trajectory: we no longer separate the public from the private realm-or public from private spaces-as readily as our predecessors did. Between gated communities on the one side and those dockland-type develop- 
ments that redefine increasing swathes of our cities and faced with increasing obstacles that regulate access to public spaces (entrance fees, metal detectors, roads designated for uses by automobiles), what we designate as 'public' space within a city arguably can no longer be subsumed underneath the designations of old.

Closely related to these historical articulations is the emergence of planning as a set of expert-led public practices. Tied in with the professionalization of procedures related to constructing the built environment and the rise of educational organisations like the École royale des ponts et chaussées (founded in 1747), planning became planning for a public largely conceived as lay people in need of direction and guidance. Initially conceived mostly as a passive recipient of planning decisions, 'the public' throughout the twentieth century nonetheless acquired qualities that defied such easy, binary categorisations. Owing perhaps to perceived colossal failures in (re-)building cities in the aftermath of World War II, expertise over public urban matters began to wane, gradually to be replaced with a redefinition of lay or everyday forms of knowledge. At any rate, gone are the days where planners could act with impunity as experts in matters pertaining to spatial design only to engage with a 'lay' public when the implementation of decisions came to occupy the agenda.

In addition to design and process-centred dimensions, a third aspect of concern here attaches to distinctly normative aspirations associated with the 'public'. Commonly linked more with political philosophy than with engineering, the idea of a 'public' correspondingly embodies sites of encounter and exchange that profit from unexpected events and happenstances as much as allowing for, indeed encouraging, the formation of opinions (Zukin, 1995). We employ the term 'public' in this sense to designate aspects of spaces that invite, rather than discourage, participation in the shaping and reshaping of society. Hence the widely acknowledged historical complicity of a public sphere with the fortunes of bourgeois (and critically protodemocratic and thus modern) society, which was in turn first investigated in the work of Jürgen Habermas (1991). The articulation of such a normatively important public in spatial configurations was a key, if often implicit, part of the planning endeavour, from the symbolic placing of sites (of government, monuments and sites of memory) to the functional embedding of a governmental logic in institutional arrangements. But here as well, chiefly as a result of technological change, spatial orderings of old no longer apply (Acconci, 1990). A public opinion that increasingly no longer requires salons to debate, cafés to read, city halls to submit forms or cinemas to watch films, will have to connect differently to the material world.

All of the contexts invoked above share a certain framing of the public as one pole of a binary distinction. Be it in the form of a 'public'-'private,' as a variant of the 'expert'-'lay' dichotomy or expressed in terms of an 'a-spatial'-'spatial' (or 'open' versus 'closed') characteristic, publics emerge as determined by and simultaneously contingent upon dualistic structural properties. At the same time, as we have seen, most twenty-first century planners no longer dwell on such crude, dualistic distinctions, preferring instead to acknowledge the situated and constructed nature of urban space. The idea, for instance, of positioning 'a public' antonymically towards some 'private' realm, practice or space is all but anathema for anyone working in academia, planning or civil society more generally. Akin to the dissolution of the old binary distinction between 'agency' and 'structure' into a wide array of practice-based approaches, the very idea of a 'public,' involving any of the material, practical and normative aspects invoked above, is today articulated as a spectrum of sorts, involving coconstitutive aspects alongside socially constructed practices. To wit, the now customary practices of 'public consultations,' 'stakeholder involvement' or similar forms of participatory planning processes would appear to involve just that: an opening of traditional opposites towards novel, spectral and process-dependant positionings. It would appear that we have learned to work with what we've got: any particular situation thus begets its own kind of public along the three axes central to this commentary.

In reality, however, such innovative practices are often hampered by an underlying notion of the (or a) public as a unified field of practice, a singular articulation of civil society. The sticking point in all of this is, of course, the possibility, actuality, non-appearance, or success of contestation. All three of the axes cited earlier encounter this challenge to their stability and epistemic or practical usefulness at some point; being able to account for its condition of possibility and impossibility is what conceptual and practical labour is all about. A contestation, we hasten to add, which itself is not cut from a unified block but comes in the form of legal forms of wrangling, refusal to co-operate, outright resistance, an insistence on non-compatible autonomy or, chiefly in the Global South, subaltern forms of experience (see Legg, 2011).

So what kind of 'public' would allow urban planners and those interesting in planning from a theoretical position to conceptualise non-dualistic and 'open' practices? An alternative approach would identify a distinctly different conceptualisation of 'the public' that attributes characteristics not found in other concepts and from thence associates practices to it. Rather than embed the notion of a public within stable frames, working and critically engaging with 'the public' and with 'public spaces' would thus appear to require its own repertoire of discourses, practices and engagements more broadly. A good starting point for an engagement of this kind would perhaps reside in the open acknowledgement of the public's phenomenal, 
rather than ideal or a priori material, character. To quote Jacques Derrida vis-à-vis the articulation of public opinion:

"Public opinion does not express itself, if one understands by this that it exists somewhere deep down, before manifesting itself in broad daylight, as such, in its phenomenality. It is phenomenal." (Derrida, 1992, p. 95)

This phenomenal articulation of 'the public', its coming-into-being as a situated constellation that does not predate the moment of its practical or epistemological enunciation as a public would potentially invite a different kind of planning as a non-binary practice, capable of addressing all possible articulations attaching to a phenomenal public. Here, intention meets affect no less legitimately than a planning map dwells on aesthetics and reason simultaneously (see for an example: Jensen, Sheller, \& Wind, 2015).

Paul Rabinow's justly famous recasting of planning (or 'urbanisme') as social engineering (Rabinow, 1989) with its accompanying shift from conceptualising the 'public' as the site of moral problems to a governmental project still provides a role model of sorts here: its explicit Foucauldian logic reconciles the phenomenal nature of 'a public' (which does not exist outside of its manifestation) with the concrete discourses, technologies and materialities that come to regulate the modern city. The public here emerges as an always contested site of interventions which in turn are characterised by often hegemonic "practice(s) of reason" (Rabinow, 1989, p. 9). Foucault's own term for the emerging constellation recast the 'public' in the form of a dispositif or 'apparatus' (Foucault 1980; for a present-day urban application, see Braun, 2014). In its contentious rendition by Giorgio Agamben, an 'apparatus' is:

"Literally anything that has in some way the capacity to capture, orient, determine, intercept, model, control, or secure the gestures, behaviors, opinions, or discourses of living beings." (Agamben, 2009, p. 14)

Here the regulation of publics and their simultaneously possible opening towards chance, alternatives or differently scaled practices becomes tangible, become decentred totalities that are ad hoc in their formation, to alter a formulation borrowed from Bruce Braun (2014, p. 52; see also the excellent introduction in Pløger, 2008). Public discourses about cities become mobile, asymmetric and change as they are scaled, encounter different publics and dynamically adapt to different milieux (McCann, 2011).

As the three dimensions of 'the public' make clear, we are not merely facing an epistemological need for change, the world of planning-or rather: the world we plan-is changing at such a rate that the juxtapositions of old no longer provide the kind of guidance that we once believed they would. How does one plan for a world in which cars drive in a semi-automated fashion? Certainly not by dis-aggregating the various parts that contribute to form a novel practice into their known properties. Bruno Latour's repeatedly used example of the speed bump (Latour, 1999, p. 186) or road-signs passively monitoring and displaying actually driven speeds in suburban neighbourhoods typify the changing realities of public space and its regulative regimes (more broadly referred to in this particular context as 'traffic planning'). Binary distinctions hold little explanatory or offer direction for normative processes in these examples. Or take the affective and also highly political question of how individual and collective voices are accorded public status in the planning process: does the thought of a unified public help us to understand what is going on (see d'Avella, 2016)? If not, why not pursue a different path?

\section{Conflict of Interests}

The author declares no conflict of interests.

\section{References}

Acconci, V. (1990). Public space in a private time. Critical Inquiry, 16(4), 900-918.

Agamben, G. (2009). What is an apparatus? In G. Agamben (Ed.), What is an apparatus? And other essays. Stanford, CA: Stanford University Press.

Ballon, H. (1991). The Paris of Henri IV. Architecture and urbanism. Cambridge, MA: MIT Press.

Braun, B. P. (2014). A new urban dispositif? Governing life in an age of climate change. Environment and Planning D: Society and Space, 32(1), 49-64.

D'Avella, N. (2016) Manifestations of the market. Public audiences and the cosmopolitics of voice in Buenos Aires. In A. Blok \& I. Farías (Eds.), Urban cosmopolitics. Agencements, assemblies, atmospheres (pp. 105-124). New York: Routledge.

DeJean, J. (2014). How Paris became Paris. The invention of the modern city. New York: Bloomsbury.

Derrida, J. (1992). Call it a day for democracy. In J. Derrida (Ed.), The other heading. Reflections on today's Europe (pp. 85-95). Bloomington, IN: Indiana University Press.

Foucault, M. (1980). The confession of the flesh. In C. Gordon (Ed.), Power/knowledge: Selected interviews and other writings (pp. 194-228). New York: Pantheon.

Habermas, J. (1991). The structural transformation of the public sphere. Cambridge, MA: MIT Press.

Jensen, O. B., Sheller, M., \& Wind, S. (2015). Together and apart: Affective ambiences and negotiation in families' everyday life and mobility. Mobilities, 
10(3), 363-382.

Latour, B. (1999). Pandora's hope: Essays on the reality of science studies. Cambridge, MA: Harvard University Press.

Legg, S. (2011). Assemblage/apparatus: Using Deleuze and Foucault. Area, 43(2), 128-133.

McCann, E. (2011). Veritable inventions: Cities, policies and assemblage. Area, 43(2), 143-147.

Pløger, J. (2008). Foucault's dispositif and the city. Planning Theory, 7(1), 51-70.
Rabinow, P. (1989). French modern: Norms and forms of the social environment. Cambridge, MA: MIT Press.

Strohmayer, U. (2010). Bridges: Different conditions of mobile possibilities. In T. Cresswell \& P. Merriman (Eds.), Mobilities: Practices, spaces, subjects (pp. 119-136). Surrey, UK: Ashgate.

Zukin, S. (1991). Landcsapes of power: From Detroit to Disney World. Berkeley, CA: University of California Press.

\section{About the Author}

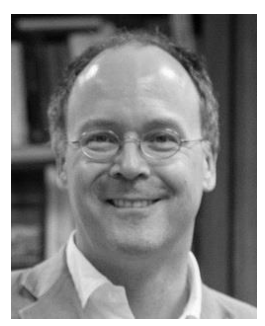

Prof. Dr. Ulf Strohmayer

Ulf Strohmayer teaches urban geography at the National University of Ireland in Galway. A native of Germany, he studied and taught in Sweden, France, Pennsylvania and Wales before settling in the West of Ireland. He has published widely on social philosophies, historical geographies of modernity and urban planning, with a particular emphasis on the geographies and histories of the French capital. 